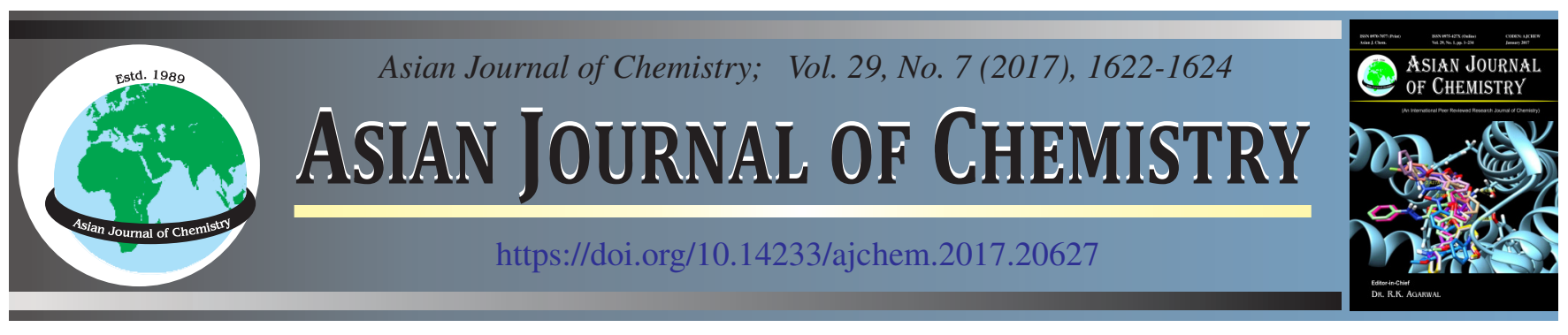

\title{
A Convenient Synthesis of 2-Methoxycarbonyl-5-iodobenzene Sulfonamide
}

\author{
Xinhong Cai ${ }^{\dagger}$, Qiulu Chen ${ }^{\dagger}$, Jing Guan, Shunze Gong, Hao Fu and Defeng Xu ${ }^{*}$
}

School of Pharmaceutical Engineering and Life Sciences, Changzhou University, Changzhou 213164, Jiangsu Province, P.R. China $\uparrow$ These authors are co-first author

*Corresponding author: Fax: +86 519 86334598; Tel: +86 519 85281008; E-mail: markxu@cczu.edu.cn

Keywords: 2-Methyl-5-nitrobenzene sulfonamide, Sulfochlorination, Ammoniation, Oxidation, Iodination, Esterification.

\section{INTRODUCTION}

The sulfonylurea herbicides with extremely high effect, low poison, low cost and other characteristics got the extensive expansion application quickly after the development, which was one of the important milestones of the agrochemical development history [1]. Iodosulfuron-methyl (1) was a sulfonylurea postemergence herbicide. Iodosulfuron-methylsodium was an active ingredient of the Alister Grande 190 OD herbicide manufactured by Bayer Crop Science, which was registered for use in Poland in 2008. Iodosulfuron-methyl can affect the activity of the acetolactate synthase (ALS) enzyme, leading to plant deformation and death, growth retardation and chlorosis [2-4]. It usually existed in the formation of methyl ester and sodium salt in the application and mainly applied to variety of gramineous weeds and broadleaved weeds that grow in spring and winter wheat, durum wheat and triticale $[5,6]$. The herbicide was safe for the cereal crops and has no influence on succeeding crops. 2-methoxycarbonyl-5-iodobenzene sulfonamide (7) and 2-amino-4methoxy-6-methyl-1,3,5-triazine were two key intermediates of iodosulfuron-methyl.

Several syntheses of 2-methoxycarbonyl-5-iodobenzene sulfonamide had been reported in the literature [7]. Diao reported the raw material was not easy to get and high cost [8]. Wang et al. reported to use the hyper-toxic potassium dichromate and iron powder [9]. A large quantity of iron mud pollution was produced in the iron powder reduction. This paper reported a convenient and efficient synthesis of 2-methoxycarbonyl-5iodobenzene sulfonamide (7) utilizing a non-toxic oxidant potassium permanganate and environment friendly hydrogenation reduction reaction using aluminum-nickel alloy catalyst in good yield. A convenient and most practical approach to the synthesis of 2-methoxycarbonyl-5-iodobenzene sulfonamide (7) involved sulfochlorination, ammoniation, oxidation, reduction and iodination reactions.<smiles>CCOC(=O)c1ccc(I)cc1S(=O)(=O)NC(=O)Nc1nc(OC)nc(OC)n1</smiles>

\section{EXPERIMENTAL}

Reagents and solvents were obtained from commercial suppliers and were used without further purification. All melting points were determined on a XT34 binocular microscope (Beijing Tech Instrument Co., China) and were not corrected. ${ }^{1} \mathrm{H}$ NMR spectra were recorded on Mercuryplus 400 (300 MHz) spectrometer, chemical shifts $(\delta)$ were reported in parts per million relative to tetramethylsilane. Chemical shifts were reported in parts per million relative to the solvent resonance as the internal standard $\left(\mathrm{CDCl}_{3}, \delta=7.16 \mathrm{ppm}\right)$. Analytical TLC and column chromatography were performed on silica gel GF254 and silica gel H60, respectively.

2-Methyl-5-nitrobenzene sulfonamide (3): To a mixture of $p$-nitrotoluene $(27.4 \mathrm{~g}, 0.20 \mathrm{~mol})$ in 1,2-dichloroethane (120 
$\mathrm{mL}$ ) was heated to $50{ }^{\circ} \mathrm{C}$, chlorosulfonic acid $(35.4 \mathrm{~g}, 0.3$ $\mathrm{mol}$ ) was added drop-wise with stirring for over $30 \mathrm{~min}$. The mixture was heated to $60{ }^{\circ} \mathrm{C}$ for $6 \mathrm{~h}$. Ice water $(500 \mathrm{~mL})$ was added at the end of the reaction with stirring. The aqueous mixture was extracted three times with 1,2-dichloromethane (75 mL), $25 \%$ ammonium hydroxide $(25 \mathrm{~mL}, 0.33 \mathrm{~mol})$ was added drop-wise combined the organic layers at $10{ }^{\circ} \mathrm{C}$, the mixture was heated to $40{ }^{\circ} \mathrm{C}$ for $2 \mathrm{~h}$. The reaction mixture was concentrated under reduced pressure in the end of the reaction. The crude residue was taken up in water $(80 \mathrm{~mL})$ and filtered, washed with water to afford off-white solid 3 (35.1 g, $81.2 \%$ yield), m.p.: 183.2-184.8 ${ }^{\circ} \mathrm{C}$ (lit. [10] m.p.: $\left.183-185{ }^{\circ} \mathrm{C}\right){ }^{1} \mathrm{H}$ NMR $\left(\mathrm{CDCl}_{3}, 300 \mathrm{MHz}\right) \delta$, ppm: $2.78(3 \mathrm{H}, \mathrm{s}), 7.24(2 \mathrm{H}, \mathrm{s}$, $\left.\mathrm{NH}_{2}\right), 7.55(1 \mathrm{H}, \mathrm{d}, J=8.4 \mathrm{~Hz}), 8.26(1 \mathrm{H}, \mathrm{d}, J=8.4 \mathrm{~Hz}), 8.82$ $(1 \mathrm{H}, \mathrm{s})$.

6-Nitrosaccharin (4): 2-Methyl-5-nitrobenzene sulfonamide (3,26.1 g, $0.10 \mathrm{~mol})$, benzyl triethyl ammonium chloride (TEBA) $(1.2 \mathrm{~g}, 5.2 \mathrm{mmol})$ and water $(250 \mathrm{~mL})$ were mixed together and heated to $95{ }^{\circ} \mathrm{C}$. The potassium permanganate $(15.7 \mathrm{~g}, 0.1 \mathrm{mmol})$ was added in batches and then added water $(50 \mathrm{~mL})$ finally. The reaction mixture was heated to $95^{\circ} \mathrm{C}$ for $8 \mathrm{~h}$. The reaction residue was filtered and washed with hot water $(80 \mathrm{~mL})$ twice, the solution was acidified with concentrated hydrochloric acid to $\mathrm{pH} 2$. A white solid was filtered off and recrystallized from ethyl alcohol to give 6-nitrosaccharin (4, 16.3 g, $71.4 \%$ yield), m.p.: 205.5-206.9 ${ }^{\circ} \mathrm{C}$ (lit. [11,12] m.p.: $212-214{ }^{\circ} \mathrm{C}$ ). ${ }^{1} \mathrm{H}$ NMR (DMSO- $\left.d_{6}, 300 \mathrm{MHz}\right) \delta$, ppm: $7.93(1 \mathrm{H}, \mathrm{d}, J=8.4 \mathrm{~Hz}), 8.41(1 \mathrm{H}, \mathrm{dd}, J=1.6,2.1 \mathrm{~Hz}), 8.47$ $(1 \mathrm{H}, \mathrm{s}), 10.6(1 \mathrm{H}, \mathrm{br}, \mathrm{NH})$.

6-Aminosaccharin (5): 6-Nitrosaccharin (4, 22.8 g, 0.10 $\mathrm{mol})$ dissolved in ethyl acetate $(120 \mathrm{~mL})$, in the presence of aluminum-nickel alloy catalyst $(3.0 \mathrm{~g})$, the theoretical amount of hydrogen had been injected for $4 \mathrm{~h}$ under pressure 2.5 MPa. The aluminum-nickel alloy catalyst was collected by filtration in the end of reaction. The reaction mixture was concentrated under reduced pressure, then recrystallized from ethyl alcohol to give the pure pale yellow solid 6-aminosaccharin $(5,18.1 \mathrm{~g}$, $90.1 \%$ yield), m.p.: $181-184{ }^{\circ} \mathrm{C}$ (lit. [12] m.p.: $180-185{ }^{\circ} \mathrm{C}$ ). ${ }^{1} \mathrm{H}$ NMR (DMSO- $\left.d_{6}\right) \delta$, ppm: $6.85(\mathrm{~d}, J=2.2 \mathrm{~Hz}, 1 \mathrm{H}), 6.92$ $(\mathrm{d}, J=2.2 \mathrm{~Hz}, 2 \mathrm{H}), 6.97(\mathrm{~d}, J=2.2 \mathrm{~Hz}, 2 \mathrm{H}), 7.62(\mathrm{~s}, 1 \mathrm{H})$, 7.64 (s, 1H), $9.8(1 \mathrm{H}, \mathrm{br}, \mathrm{NH})$.

6-Iodosaccharin (6): 6-Aminosaccharin (5, $19.8 \mathrm{~g}, 0.10$ mol), acetic acid $(150 \mathrm{~mL})$, water $(30 \mathrm{~mL})$ and concentrated hydrochloric acid $(30 \mathrm{~mL})$ were mixed together and cooled to $-5^{\circ} \mathrm{C}$, then the sodium nitrite $(8.4 \mathrm{~g}, 0.12 \mathrm{~mol})$ and water $(50$ $\mathrm{mL}$ ) were added drop-wise with stirring at $0{ }^{\circ} \mathrm{C}$ for $1 \mathrm{~h}$. The potassium iodide $(16.6 \mathrm{~g}, 0.10 \mathrm{~mol})$ was dissolved in water $(100 \mathrm{~mL})$ was added drop-wise and the reaction mixture was heated to $50{ }^{\circ} \mathrm{C}$ for $1 \mathrm{~h}$. In the end of reaction, the mixture was cooled to room temperature, filtrated and washed with water, recrystallized from ethyl alcohol to give bronzing solid 6iodosaccharin $(6,21.9 \mathrm{~g}, 70.8 \%$ yield $)$, m.p.: $224.6-227.5^{\circ} \mathrm{C}$ (lit. [13] m.p.: 224-226 $\left.{ }^{\circ} \mathrm{C}\right) .{ }^{1} \mathrm{H}$ NMR $\left(\mathrm{CDCl}_{3}\right) \delta$, ppm: 7.73 $(\mathrm{d}, J=8.0 \mathrm{~Hz}, 1 \mathrm{H}), 8.19(\mathrm{~d}, J=8.0 \mathrm{~Hz}, 1 \mathrm{H}), 8.24(\mathrm{~s}, 1 \mathrm{H})$, 10.2(1H, br, NH).

2-Methoxycarbonyl-5-iodobenzene sulfonamide (7): 6-Iodosaccharin $(6,31.0 \mathrm{~g}, 0.10 \mathrm{~mol})$ was dissolved in methanol $(200 \mathrm{~mL})$, concentrated sulfuric acid $(2 \mathrm{~mL})$ was added dropwise with stirring, the mixture was heated under reflux for $6 \mathrm{~h}$. The mixture was cooled to room temperature. In the end of reaction, the methanol was removed and the residue was taken up in sodium hydrogen carbonate saturated aqueous (120 $\mathrm{mL}$ ) to adjust $\mathrm{pH} 8$, filtered and washed with water, recrystallized from methanol to afford 2-methoxycarbonyl-5-iodobenzene sulfonamide 7 (32.1g, $94.1 \%$ yield), m.p.: 175-179 ${ }^{\circ} \mathrm{C}$ (lit. [14] m.p.: $176-177^{\circ} \mathrm{C}$ ).

\section{RESULTS AND DISCUSSION}

Recently studied using the sulfonylurea class of herbicides and a key intermediate 2-methoxycarbonyl-5-iodobenzene sulfonamide (7), showed that the efficient synthesis of 6aminosaccharin (5) with 6-nitrosaccharin (4) in the presence of aluminum-nickel alloy catalyst afforded 2-methoxycarbonyl5 -iodobenzene sulfonamide in very high yields, meantime, the optimization of the synthetic conditions for 6-nitrosaccharin was conducted.

Potassium dichromate is a hyper-toxic oxidant, which had limited use in the world. Generally, non-toxic or environ-<smiles>Cc1ccc([N+](=O)[O-])cc1</smiles>

2<smiles>Nc1ccc2c(c1)S(=O)(=O)NC2=O</smiles>

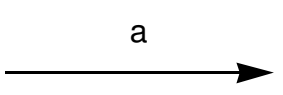

$(81.2 \%)$<smiles>Cc1ccc([N+](=O)[O-])cc1S(N)(=O)=O</smiles>

3

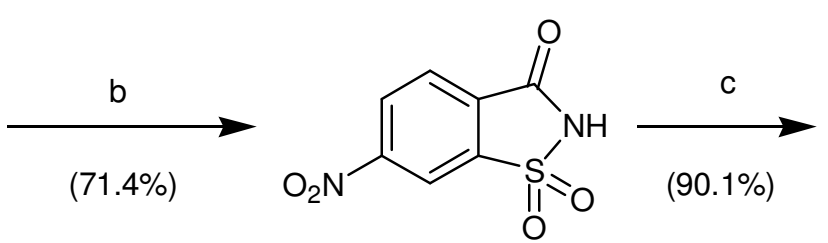

4

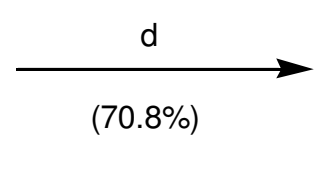<smiles>O=C1NS(=O)(=O)c2cc(I)ccc21</smiles>

6<smiles>COC(=O)c1ccc(I)cc1S(N)(=O)=O</smiles>

7
b. $\mathrm{KMnO}_{4} \cdot \mathrm{TEBA} / \mathrm{H}_{2} \mathrm{O}$
a. $\mathrm{HSO}_{3} \mathrm{Cl}$. $\mathrm{NH}_{3}$
c. $\mathrm{H}_{2} \cdot \mathrm{Ni}-\mathrm{Al}$
d. $\mathrm{NaNO}_{2} / \mathrm{HAc} . \mathrm{KI}$
e. $\mathrm{CH}_{3} \mathrm{OH} . \mathrm{H}_{2} \mathrm{SO}_{4}$

Scheme-I: Synthesis of 2-methoxycarbonyl-5-iodobenzene sulfonamide 
mentally friendly oxidant for manufacture should be used. Although potassium permanganate was lower than potassium dichromate in the performance of oxidation, it was a non-toxic oxidant. Potassium permanganate was selected as an oxidant and it was found that the phase translation catalytic benzyl triethyl ammonium chloride could improve the yield of 6-nitrosaccharin. The yield of oxidation was $71.4 \%$.

The traditional reducing process usually adopts iron powder reduction, which produces the serious pollution of iron mud. The hydrogenation reduction technique was an environmentally friendly process in the chemical industry. The 6-nitrosaccharin was treated with hydrogenation reduction using aluminum-nickel alloy catalyst to give 6-aminosaccharin in $94.1 \%$ yield.

\section{Conclusion}

We described a convenient efficient synthesis of 2-methoxycarbonyl-5-iodobenzene sulfonamide (7). This present contribution described the utilization of aluminum-nickel alloy catalyst as an environmentally friendly process for the hydrogenation of 6-nitrosaccharin. A convenient and concise process for the synthesis 2-methoxycarbonyl-5-iodo benzene sulfonamide had been proven to be practical. The current method presented a very promising synthetic process for 2-methoxycarbonyl-5iodobenzene sulfonamide because of the following advantages:

- Non-toxic potassium permanganate to replace toxic oxidant sodium dichromate.

- Aluminum-nickel alloy catalytic replaced iron reduction which controlled pollution source from raw material.

- The clean process reported in this paper can be easily developed into larger-scale preparation of 2-methoxycarbonyl5-iodobenzene sulfonamide for new sulfonylurea herbicides development.

\section{ACKNOWLEDGEMENTS}

This project is supported by the Introduction Talent Fund of Changzhou University, China.

\section{REFERENCES}

1. J.S. Liu, J.J. Kou and G.L. Liu, Agrochemicals, 46, 145 (2007).

2. D. J. Nevill and C. H. Riehen, Broad-Spectrum Pre- or Post=Emergence Herbicidal Composition, Patent-DE19834627A (1983).

3. M. Witschel, C. Zagar and A. Landes, Synergistically Acting Herbicidal Mixtures, Patent-ZA200508237(B) (2005).

4. R. Hain, G. Johann and U. Bickers, Use of Als Inhibitor Herbicides for Control of Unwanted Vegetation in Als Inhibitor Herbicide Tolerant Brassica, Such As B. Napus, Plants, Patent WO2012150333(A1) (2012).

5. L. Xu, H. Shu, Y. Liu and M. Trudell, ChemInform, 62, 7902 (2006); https://doi.org/10.1016/j.tet.2006.05.038.

6. H.C. Li, K. Sun and M.H. Zhang, Agrochemicals, 53, 227 (2014).

7. O. Ort, K. Bauer and H. Bieringer, Arylsulfonylureas, Processes for their Preparation and their use as Herbicides and Growth Regulators, Patent US5463081A1 (1995).

8. J. Diao and F. Ao, Agrochemicals, 46, 484 (2007).

9. Z. Wang, F. Kong and Z. Cao, J. Suzhou Univ., 25, 66 (2009).

10. H. Kamogawa, S. Yamamoto and M. Nanasawa, Bull. Chem. Soc. Jap., 55, 3824 (1982); https://doi.org/10.1246/bcsj.55.3824.

11. H. Zhang, C. Yang, W. Lu, J. Huang, W. Zhu, H. Li, Y. Xu and X. Qian, Chem. Commun., 47, 8301 (2011); https://doi.org/10.1039/c1cc12386f

12. A. Warren and G.H. Hamor, J. Pharm. Sci., 50, 625 (1961); https://doi.org/10.1002/jps.2600500723.

13. L. Han, L. Wang, X. Hou, H. Fu, W. Song, W. Tang and H. Fang, Med. Chem., 22, 1529 (2014); https://doi.org/10.1016/j.bmc.2014.01.045.

14. N. Gençer, D. Demir, F. Sonmez and M. Kucukislamoglu, Med. Chem., 20, 2811 (2012); https://doi.org/10.1016/j.bmc.2012.03.033. 